\title{
Brief Discussion on Accommodation
}

\section{Dr Partha Haradhan Chowdhury ${ }^{1 *}$ and Brinda Haren Shah ${ }^{2}$}

${ }^{1}$ Ph.D. in Optometry (Gujarat State Government University) and Professor and Principal, Shree Satchandi Jankalyan Samiti Eye Institute - Pauri, Uttarakhand, India

${ }^{2}$ M. OPTOM, Practitioner, Ahmedabad, Gujarat, India

*Corresponding Author: Dr Partha Haradhan Chowdhury, Ph.D. in Optometry (Gujarat State Government University) and Professor and Principal, Shree Satchandi Jankalyan Samiti Eye Institute - Pauri, Uttarakhand, India.
Received: March 23, 2021

Published: April 15, 2021

(C) All rights are reserved by Dr Partha

Haradhan Chowdhury and Brinda Haren

Shah.

\section{Abstract}

This paper describes about introduction to accommodation, it components, factors and its treatment modalities.

Keywords: Accommodation; Modalities; Components

\section{Introduction}

Accommodation is a condition where parallel rays of light are coming from near object and brought to focus on the foveal area by changing the anterior surface of the crystalline lens. It is a triad mechanism. i.e. (Accommodation + Convergence + Pupil constriction). It is called Synkinesis also.

E.g. When patient is looking at a distance object usually at 6-meter distance, then accommodation does not play role. When patient is looking at $40 \mathrm{~cm}$ at that time accommodation plays role.

During accommodation, ciliary muscle contracts and suspensory ligament is in relax condition.

With increasing age, the elasticity of the crystalline lens is reduced that's why lens is getting problem to bulge.

Components of accommodation

1. Reflex accommodation

2. Vergence accommodation
3. Proximal accommodation

4. Toxic accommodation.

Reflex accommodation

It is an automatic mechanism. Up to $2.00 \mathrm{D}$ patient is able to control it (Monocular/binocular). Reflex accommodation is the most important component of accommodation.

\section{Vergence accommodation}

It is induced by fusional convergence. It means during fusion when eye converges then accommodation is stimulated which will induce $\mathrm{CA} / \mathrm{C}$ ratio.

\section{Proximal accommodation}

It occurs due to nearness of an object at $3 \mathrm{~m}$ distance.

Toxic accommodation

Toxic accommodation is created without blur. When patient sits in the dark room away from the wall at $3 \mathrm{~m}$ then it is stimulated. 
In this situation, biochemical composition of the crystalline lens is changed. With increase in age toxic accommodation is reduced.

Factors:

- Far point

- Near point

- Range of accommodation

- Amplitude of accommodation.

By the Hoffster's formula we can able to know the amplitude of accommodation.

$18.5-$ Age/3.

Always it is remembered that with increase in age amplitude of accommodation is changed and up to $2 \mathrm{D}$ it is tolerable.

In some specific reasons, changes in accommodation are found which is called anomalous of accommodation.

They are:

- Insufficiency of accommodation

- Excess of accommodation

- Infacility of accommodation.

In all the above cases, amplitude of accommodation is changed up to $2.00 \mathrm{D}$.

These abnormalities of accommodation can be treated with vision therapy and meditation also [1-3].

\section{Bibliography}

1. William J Benjamin. "Borish's Clinical Refraction". $2^{\text {nd }}$ Edition (2006).

2. Theodore Grosvenor and Theodore P Grosvenor. "Primary Care Optometry". $5^{\text {th }}$ Edition (2007).

3. Sir Stewart Duke-Elder and David Abrams. "Duke Elder's Practice of refraction" (1978).

\section{Assets from publication with us}

- Prompt Acknowledgement after receiving the article

- Thorough Double blinded peer review

- Rapid Publication

- Issue of Publication Certificate

- High visibility of your Published work

Website: www.actascientific.com/

Submit Article: www.actascientific.com/submission.php

Email us: editor@actascientific.com

Contact us: +919182824667 